\title{
Assessing Determinants on Job Creation at the Firm Level Swedish Micro Firm Data
}

\author{
Darush Yazdanfar ${ }^{1} \&$ A. Khalik Salman ${ }^{1}$ \\ ${ }^{1}$ Department of Social Sciences, Mid Sweden University, Sweden \\ Correspondence: Darush Yazdanfar, Department of Social Sciences, Mid Sweden University, Regementsgatan \\ 25-27, Östersund 831 25, Sweden. Tel: 46-730-989-2800. E-mail: darush.yazdanfar@miun.se
}

Received: September 27, 2012

Accepted: October 22, $2012 \quad$ Online Published: October 30, 2012

doi:10.5539/ijef.v4n12p105

URL: http://dx.doi.org/10.5539/ijef.v4n12p105

\begin{abstract}
This study analyses job-creation determinants at the firm level for a panel of Swedish micro firms across four industry sectors, using the GMM (Generalized Method of Moments) system to analyse a database consisting of 12532 Swedish micro firms during 2007. It was found that the firms' size and age, the importance of debt financing and increased availability of liquidity are positively related to job creation as well as industry affiliation. Finally, the results suggest that a resource-based approach is at work in explaining job creation in micro firms. Unlike the majority of previous studies, this study is characterized by being based on a large and cross-sectoral firm-level dataset, testing a number of hypotheses driven from the resource-based approach. The present study contributes to the literature on the determinants of employment at the firm level as it investigates the importance of liquidity and financial leverage to firm labour demand dynamics in Sweden.
\end{abstract}

Keywords: job-creation determinants, micro firms, GMM system, liquidity, financial leverage

\section{Introduction}

The importance of small businesses is well acknowledged as a major source of jobs, not only in Sweden but also internationally. The hiring of labour in any firm depends, like any other investment, on its financial position. Nevertheless, little is known about the relationship between financing and job creation in the context of micro firms. As micro firms face credit constraints, this question is especially important. The reason is that access to external finance is a crucial determinant of business expansion, growth and thereby job creation. According to previous studies, liquidity constraints generally influence the firm's investment expenditure, demand for products, labour and services (Arnold, 2002; Gertler \& Gilchrist, 1993; Greenwald \& Stiglitz, 1993; Hubbard, 1998). Consequently, firms' employment decisions, like any fixed capital investment decision, are affected by firms' financial constraints. Thus, liquidity access is an important precondition for firm investment and growth (Audretsch \& Elston, 2002; Beck, Demirgüç-Kunt, \& Maksimovic, 2005; Carpenter \& Petersen, 2002; Fagiolo \& Luzzi, 2006; Hutchinson \& Xavier, 2006; Oliveira \& Fortunato, 2006). However, liquidity access has generally been regarded as a common challenge for small and young businesses (Evans \& Jovanovic, 1989). In addition, such firms typically experience difficulties raising capital from external sources (Hamilton \& Fox, 1998; Stiglitz \& Weiss, 1981). The explanation is high information asymmetry costs on the one hand, and high agency costs on the other, which force small businesses to raise capital internally (Carpenter \& Petersen, 2002; Myers, 1984; Myers \& Majluf, 1984). The linkage between this financing difficulty and issues such as fixed capital investment, inventory investment and R\&D investment has been highlighted by previous research (Benito, 2005; Bond, Harhof, \& Van Reenen, 1999; Carpenter \& Petersen, 2002; Guariglia, 2006).

The interaction between labour and financial market institutions has been regarded as one of the important determinants for aggregate employment, based on the industrial organization perspective or on a liquidity constraint approach (Benito \& Hernando, 2008; Nickell \& Nicolitsas, 1999; Nickell \& Wadhwani, 1991; Sharpe,1994). However, the association between financing difficulty and employment at the firm level has been less frequent and subject to only a few empirical studies (Nickell \& Nicolitsas, 1999; Sharpe, 1994). To fill these gaps in the literature, the purpose of the current study is to empirically examine the firm-level job-creation determinants among Swedish micro firms. The reason for focusing on micro firms is that micro firms play a very crucial role in the Swedish economy and account for over $96 \%$ of firms and employ more than $50 \%$ of the Swedish labour force (SCB: Statistics Sweden, 2011). These firms have been an important engine of job creation 
for the Swedish economy over the last three decades. However, there has been little research investigating the employment determinant among them. Thus, since micro firms play an important role in the Swedish economy with regard to job creation, the present study is a contribution to the literature on micro firm employment. In addition, since the Swedish economy is unique in terms of, for example, its welfare system and labour market, this study focuses on an interesting context for this study. This paper is organized as follows: The next section describes the theoretical framework and summarizes previous research. Section 3 elaborates on the selection of variables, research hypothesis, data, and method. Section 4 reports the data analysis and empirical results. Section 5 presents the conclusion of the study.

\section{Theoretical Framework and Previous Empirical Studies}

\subsection{Theoretical Framework}

Unlike many previous studies, this study is based on the deterministic resource-based approach, focusing on firm-level job-creation determinants. The term 'resources' has, in accordance with the relevant literature, a broad meaning, consisting of all types of assets, such as cash, debt capital, management capabilities, networking, organizational processes, firm attributes, information and knowledge (Conner \& Prahalad, 1996; Wernerfelt, 1984). From the viewpoint of the resource-based approach, firms can achieve high performance in terms of various measurements, such as profitability, change in sales, and job creation, through the use of different types of resources. In other words, the increased availability of resources will have a positive impact on investment expenditure and the demand for labour, products and services. Accordingly, financial resource can quite easily be transformed into other types of resources which lead to increased growth in terms of, for example, higher profitability, larger market share and higher employment. Thus, increased availability of financial resources in terms of liquidity generated by retained income and debt capital enable firms to develop their growth capacity in different ways, for example, by using new technology, acquiring labour and entering new markets (Castrogiovanni, 1996). From the new-Keynesian perspective, market imperfections, caused by information asymmetries, agency costs, moral hazards and adjustment costs, partly explain firms' access to financial resources and thereby their demand for labour (Arnold, 2002; Greenwald \& Stiglitz, 1993). A number of previous studies have found evidence that increased liquidity availability generally impacts positively on fixed capital investment (e.g. Bond \& Meghir, 1994; Fazzari, Hubbard, \& Petersen, 1988). Some other works and, in particular, the empirical evidence suggest that financial pressure affects employment (Benito \& Hernando, 2002; Bond \& Meghir, 1994; Bond \& Van Reenen, 2007; Cantor 1990; Nickell \& Nicolitsas 1999; Sharpe 1994). As suggested by Modigliani \& Miller (1958) there is no association between a firm's financial structure and its value, implying that a firm's financing choice has no effect on its real operation. However, market imperfections in terms of asymmetric information problems, moral hazards, agency conflicts between shareholders and managers, labour market regulations, and distortionary taxation, lead to the separation of investment and financing decisions. Small firms are shown to suffer more from the problems related to market imperfections and, in particular, liquidity constraints than larger firms (Myers, 1984; Myers \& Majluf, 1984; Oliveira \& Fortunato, 2006). Thus, liquidity constraints are even more important for more vulnerable firms, that is, small businesses at start-up (Myers, 1984; Myers \& Majluf, 1984). According to the resource-based approach, larger firms exploit the economies of scale, they tend be more diversified and suffer less from information asymmetries, moral hazards, financial distress, cash flow volatility and bankruptcy risk. As a result they have better debt capacity, and they can borrow under better conditions and so they are more likely to suffer less from liquidity constraints and thereby have better opportunities to employ labour. Moreover, in agreement with the approach, older firms will have considerably more resources in terms of knowledge, networks, markets and communications than younger firms, since older firms acquire resources over time (Autio, 2005; Jovanovic, 1982). In addition, age is negatively associated with information asymmetry, implying that the older the firm the easier it is to obtain external financial resources. On the other hand, young firms without established credit histories and reputations face more problems related to information asymmetry in obtaining credit. Age, therefore, is assumed to be positively related to access to debt capital, liquidity and job creation (Audretsch, 1995; Broersma \& Gautier, 1997; Oliveira \& Fortunato, 2006). Financial constraints in terms of low debt capacity and limited access to liquidity are regarded as one of the most important barriers to employment (Yazdanfar, 2011). Many of these researchers also confirm an association between these challenges and employment. The association between firm liquidity constraints and investment, growth and employment has been highlighted by previous research (Acemoglu, 2001; Oliveira \& Fortunato, 2006).

The impacts of the independent variables, size, age, leverage, liquidity, and industry affiliation on employment may overlap. The effect of the industry on job creation has, therefore, been controlled to capture industry-specific differences among various industries. Thus, the employment level is expected to vary across 
industries. Job creation in an industry depends on variables such as technology type, labour cost, and capital. The productivity level can also change over time, reflecting the change in these factors over time.

\subsection{Previous Empirical Studies}

The empirical research into the impacts of firm-level financial determinants on job creation is limited to a few studies, with mixed results leading to controversy. For instance, Cantor (1990) reports that highly leveraged firms tend to have more volatile employment and capital investment. Likewise, Nickell \& Wadhwani (1991) confirm that employment decreases with the firm's leverage ratio among a set consisting of over 200 British firms. Sharpe (1994) also found evidence that the interest rate and the firm's leverage had a negative effect on employment. On the contrary, Greenwald and Stiglitz (1993) report that a firm's financial constraints caused by information asymmetries negatively influence the demand for labour. Similarly, according to Acemoglu (2001), financial constraints are regarded as obstacles to employment since they hinder new investment, especially in new innovative firms that create jobs. Nickell \& Nicolitsas (1999) found evidence that there was a negative association between the employment level and the cost of capital measured in terms of the ratio of interest payments to cash flow. Furthermore, Arnold (2002) reports an association between financial constraints and employment. Accordingly, employment declines among firms facing financial constraints caused by information asymmetries. As reviewed above, there is limited prior research regarding the determinants of employment at the firm level. Thus, this study is an attempt to incorporate this literature by obtaining empirical evidence about the relationship between firm-level determinants and employment.

\section{Selection of Variables, The Research Hypotheses, Sample and Model Specification}

\subsection{Selection of Variables}

Based on the purpose of the study and the relevant literature and in order to explain the change in the independent variable, employment, four independent variables, size, age, liquidity and industry affiliation, and leverage, are incorporated into the GMM model. In addition, two further variables, profitability and tangibility, have been identified and used as instrumental variables. These variables are defined in the following section.

\subsubsection{The Dependent Variable}

The dependent variable, job creation, is expected to be affected by changes in liquidity generated by leverage. Job creation is measured as the number of employees among the firms.

\subsubsection{The Independent Variables}

Based on previous studies, a number of variables have been identified and investigated as being associated with job creation. These studies have analysed firm-level data and found relationships between employment and variables such as size (Broersma \& Gautier, 1997; Hall, 1987; Oliveira \& Fortunato, 2006; Singh \& Whittington, 1975), age (Audretsch, 1995; Broersma \& Gautier, 1997; Jovanovic, 1982; Oliveira \& Fortunato, 2006), leverage (Carpenter \& Petersen, 2002; Fazzari, Hubbard, \& Petersen, 1988, Heisz and LaRochelle-Côté, 2004; Lang, Ofek, \& Stulz 1996; Yazdanfar, 2011), liquidity (Acemoglu, 2001; Funke, Maurer, Siddiqui, \& Strulik, 1998; Winker, 1999). Since firm size and age have an influence on information asymmetry, they are relevant when studying liquidity constraints (Myers, 1984; Myers \& Majluf, 1984). In this study, the natural logarithm of sales is used as a proxy for size (SIZE). This measure is the most common proxy for size among previous studies. These proxies, as well as all other proxies in this study, refer to book values. Moreover, the proxy variable for age is the natural logarithm number of years between the firm's inception and the year of data collection. The leverage has been defined as the book value of total liabilities divided by total assets. In addition, liquidity is measured mostly in terms of current assets divided by total assets. Finally, since the job-creation level is expected to be affected by industry affiliation and to vary across industries, a dummy variable is included in the model.

\subsection{Hypotheses}

As mentioned above, unlike much previous research, this study is based on the resource-based approach, implying that the independent firm-level variables, size, age, leverage and liquidity, positively influence job creation (Audretsch, 1995; Autio, 2005; Hall, 1987; Lang, Ofek, \& Stulz 1996).

Hypothesis 1 . Firm size is expected to positively affect job creation.

Hypothesis 2. Firm age is expected to positively influence the job-creation level.

Hypothesis 3. Leverage is expected to positively affect job creation.

Hypothesis 4. Liquidity is expected to positively affect job creation. 
Hypothesis 5. A firm's industry affiliation influences its job-creation level.

\subsection{Data}

The preliminary panel data consist of unlisted limited liability Swedish micro firms for the period 2007. The annual data was extracted from Affärsdata, a comprehensive commercial database which compiles accounting records for all registered limited liability firms in Sweden. The sample thus contains micro firms with 1-9 employees across four industry sectors, trade, transport, health and metal. Observations including negative figures on the balance sheet and outliers (those outside the interval defined by plus/minus five times the interquartile range) have been excluded.

\subsection{Model Specification}

The GMM system has been used as the main method in this study to overcome problems such as unobserved individual effects, likely endogeneity of the explanatory variables and autoregressive processes in the data concerning the dependent variable, which are associated with panel data. This method has been suggested by Arellano \& Bond (1991) for analysis of the panels with a limited number of years and a considerable number of observations.

The following model has been formulated to identify and quantify the variables that explain the job-creation level in a sample of micro firms. The variables included are, size, age, leverage ratio, liquidity ratio, and industry dummy, and two financial variables leverage and liquidity:

For the complete sample

$\mathrm{Job}_{i, t}=\alpha_{t}+\beta_{1}$ Size $_{i, t}+\beta_{2}$ Age $_{i, t}+\beta_{3} \operatorname{Liq}_{i, t}+\beta_{4} \operatorname{Lev}_{i, t}+\beta_{5}$ Indus $_{i, t}+\mu_{i t}$

$\alpha_{\mathrm{t}}=$ constant

$\mathrm{Job}_{i, t}=$ is the natural logarithm of the number of employees in the current year

Size $_{\mathrm{i}, \mathrm{t}}=$ size of firm $i$ at time $t$; is measured as the natural logarithm of the firm's book value of sale

Agei, $t=$ age of firm $i$ at time $t$; age is the natural logarithm of the number of years since the firm's inception as of the year of data collection

$\mathrm{LEV}_{\mathrm{i}, \mathrm{t}}=$ financial leverage ratio between total liabilities and total assets

$\mathrm{Liq}_{\mathrm{i}, \mathrm{t}}=$ ratio between current assets and short-term debt

Indus $_{i, t}=$ categorical variable, industry

$\varepsilon_{i t}=$ error term

\section{Empirical Results}

In this section we present the most important results regarding the descriptive statistics and correlation analysis, and the estimation results of the results of GMM system analysis.

\subsection{Results of the Descriptive Analysis}

The descriptive statistics presented in Table 1 are employed to illustrate the industry classification of the sampled firms using the single-digit SIC code, mean and standard deviation of the variables included in the study. As reported in the table, $25 \%$ of the firms operate in retail trade, but there is also significant representation in health care sectors $(30 \%)$ and transportation (28\%), with the remaining (17\%) in the metal sector. Thus, service firms (i.e., retail trade, health care, and transportation) are highly represented in our sample (83\%), reflecting the fact that most Swedish micro firms operate in the service sector. Moreover, the firms included in the sample fall into the category 'micro' firm sector, with fewer than ten employees and an average of three employees per firm. The firms are also characterized by an average age of around 19 years, implying that the firms are, in general, established and mature. However, firms in the retail trade industry generally seem to be older than those in the other industries. As confirmed by the descriptive statistics, the sample is characterized by homogeneity among the sectors with regard to size since its standard deviation is lower than the respective averages. Since the standard deviation of liquidity is above the respective averages it can be concluded that this variable is considerably volatile across different industries. 
Table 1. Descriptive table of the variables included in the study

\begin{tabular}{lrrrrr}
\hline & Retail trade & Transport & Metal & Healthcare & Total \\
\hline N (Firms) & 3080 & 3526 & 2210 & 3716 & 12532 \\
Percentage (Firms) & $25 \%$ & $28 \%$ & $17 \%$ & $30 \%$ & $100 \%$ \\
Employees (mean) & 3.630 & 3.039 & 3.827 & 3.014 & 3.316 \\
Std. Deviation & 2.137 & 2.171 & 2.445 & 2.157 & 2.236 \\
Age (mean) & 21.931 & 18.181 & 20.325 & 18.206 & 19.488 \\
Std. Deviation & 14.386 & 10.831 & 12.244 & 10.756 & 12.130 \\
Size (mean) & 3.648 & 3.408 & 3.493 & 3.392 & 3.477 \\
Std. Deviation & 0.439 & 0.401 & 0.429 & 0.402 & 0.428 \\
Liquidity (mean) & 1.558 & 2.821 & 2.426 & 2.747 & 2.419 \\
Std. Deviation & 3.202 & 4.788 & 2.623 & 4.600 & 4.088 \\
Leverage (mean) & 0.520 & 0.449 & 0.443 & 0.450 & 0.466 \\
Std. Deviation & 0.136 & 0.169 & 0.160 & 0.169 & 0.163 \\
J-B p-value & 0.000 & 0.000 & 0.000 & 0.000 & 0.000 \\
\hline
\end{tabular}

$\mathrm{J}$-B p-values are reported for the Jarque-Bera normality test: $\mathrm{H} 0=$ normality.

In addition, although there are considerable differences between industries in term of liquidity ratios, the results show no considerable differences between them with regard to size, age and leverage.

\subsection{Results of the Correlation Analysis}

To examine the direction and significance of the relationships among the variables included in the model, Pearson's correlation analysis has been conducted. Table 2 displays the results of this analysis. Accordingly, a positive and significant correlation between a firm's size, age, liquidity, financial leverage and job-creation level is observed, implying that the large, older firms with higher liquidity and a higher leverage ratio are characterized by higher levels of job creation. Moreover, there is a positive and significant relationship between, size, age and leverage indicating that firm leverage appears to increase with size and age. This can be interpreted as larger and older firms have smaller information asymmetry and thereby fewer problems in obtaining debt capital.

Table 2. Results of the correlation analysis

\begin{tabular}{lllllll}
\hline & Employees & Size & Age & Liquidity & Leverage & Industry \\
\hline Employees & 1 & $.745^{* *}$ & $.116^{* *}$ & $-.125^{* *}$ & $.159^{* *}$ & $-.046^{* *}$ \\
& & 0.000 & 0.000 & 0.000 & 0.000 & 0.000 \\
Size & $.745^{* *}$ & 1 & $.112^{* *}$ & $-.186^{* *}$ & $.217^{* *}$ & $-.162^{* *}$ \\
& 0.000 & & 0.000 & 0.000 & 0.000 & 0.000 \\
Age & $.116^{* *}$ & $.112^{* *}$ & 1 & $.057^{* *}$ & $-.159^{* *}$ & $-.058^{* *}$ \\
& 0.000 & 0.000 & & 0.000 & 0.000 & 0.000 \\
Liquidity & $-.125^{* *}$ & $-.186^{* *}$ & $.057^{* *}$ & 1 & $-.446^{* *}$ & $.076^{* *}$ \\
& 0.000 & 0.000 & 0.000 & & 0.000 & 0.000 \\
Leverage & $.159^{* *}$ & $.217^{* *}$ & $-.159^{* *}$ & $-.446^{* *}$ & 1 & $-.135^{* *}$ \\
& 0.000 & 0.000 & 0.000 & 0.000 & & 0.000 \\
Industry & $-.046^{* *}$ & $-.162^{* *}$ & $-.058^{* *}$ & $.076^{* *}$ & $-.135^{* *}$ & 1 \\
& 0.000 & 0.000 & 0.000 & 0.000 & 0.000 & \\
$\mathrm{~N}$ & 12532 & 12532 & 12532 & 12532 & 12532 & 12532 \\
$\mathrm{~J}-\mathrm{B}$ p-value & 0.0000 & 0.0001 & 0.0002 & 0.0003 & 0.0004 & 0.0007 \\
\hline
\end{tabular}

** Correlation is significant at the 0.01 level (2-tailed). * Correlation is significant at the 0.05 level (2-tailed). J-B p-values are reported for the Jarque-Bera normality test: $\mathrm{H} 0=$ normality at the 0.01 level.

As shown in the above table (Table 2), the results of the Jarque-Bera tests of data normality (J-B p-value) confirm that the observations are normally distributed at the 0.01 level. 


\subsection{Results of the GMM System}

Referring to the results of the GMM system presented in Table 3, all of the coefficients are in the predicted direction and statistically significant as the p-values are less than 0.05 . Thus, job creation among sample firms is found to be affected by the determinants firm size, age, liquidity, leverage and industry affiliation.

Table 3. Results of GMM system analysis

\begin{tabular}{lllllll}
\hline & Coef. & Std. Err. & $\mathrm{Z}$ & $\mathrm{P}>\mathrm{Z}$ & {$[95 \%$ Conf. } & Interval] \\
\hline Size & 0.5060104 & 0.0116577 & 43.41 & 0.000 & 0.4831617 & 0.528859 \\
Age & 0.103033 & 0.0175372 & 5.88 & 0.000 & 0.0686608 & 0.137405 \\
Liquidity & 0.003784 & 0.003784 & 3.42 & 0.001 & 0.005528 & 0.0203608 \\
Leverage & 0.3300078 & 0.1914641 & 4.18 & 0.000 & 0.4241934 & 1.174719 \\
Industry & 0.0020611 & 0.0020611 & 8.86 & 0.000 & 0.014232 & 0.0223114 \\
Constant & -1.13997 & 0.0884979 & -21.71 & 0.000 & -2.09477 & -1.747873 \\
\hline Wald chi2(5) $=12905.30$ & & Root MSE $=.21728$ \\
Prob $>$ chi2 $=0.0000$ & \multicolumn{5}{r}{ Hansen's J chi2 $(1)=2.21634(\mathrm{p}=0.1366)$} \\
R-squared $=0.4815$ & \multicolumn{5}{c}{ GMM statistic chi2 $(1)=23.6069(\mathrm{p}=0.0000)$} \\
\hline
\end{tabular}

All coefficients are significant at the 0.01 level; Breusch-Pagan/Cook-Weisberg test for heteroscedasticity $H_{0}$ : Constant variance, $\operatorname{chi}^{2}(1)=$ 2302.46, Prob $>\mathrm{chi}^{2}=0.0000$. (VIF) $=1.981$. J-B p-value: 0.000 . GMM C statistic: Test of endogeneity (orthogonality conditions)

Consistent with expectations, the size coefficient is positive and statistically significant. The positive influence of size on job creation may be explained because larger firms tend to be related to greater economies of scale and better possibilities of creating jobs. Similarly, the age coefficient is positive and statistically significant, meaning that older firms tend to require more employees than younger ones. As the liquidity coefficient is positive and statistically significant, the firm with better access to cash has a better chance of financing the hiring of labour. Furthermore, leverage also has a positive relationship with job creation implying that firms with a higher leverage ratio display a higher demand for labour. Finally, industry affiliation has a positive and statistically significant influence on job creation and partly explains the variation in job creation across different sectors. Overall, the empirical findings presented above support all the hypotheses outlined in section 3.

The high R-squared statistic suggests that the model explains a considerable part, around $48 \%$ of the change in the dependent variable. The other variables, such as organizational, legal, managerial and macroeconomic factors, may account for the remaining part of the change in job creation. The Wald statistics (Wald chi 2(5) $=12905.30$, p: 0.0000) confirm the validity of the estimated model implying that all the coefficients are statistically significant at the $1 \%$ confidence level. As reported in Table 3, the Jarque-Bera (J-B p-value p: 0.0000) test of normality indicates that the data are normally distributed (i.e., the JB p-values of all variables of the sample are lower than 0.001). In addition, the results of the Breusch-Pagan/Cook-Weisberg diagnostic analyses indicate no risk of heteroscedasticity. Moreover, the variance inflation factor (VIF) test, carried out to test the models for multi-collinearity, indicates that multi-collinearity is not a problem in the estimates. Finally, heteroscedasticity/serial correlation, consistent with Hansen-Sargan's test of over-identifying restrictions, is performed indicating that the instruments are valid instruments, that is, uncorrelated with the disturbance term, and that the excluded instruments are correctly excluded from the estimated equation.

To sum up, as shown by the empirical findings, in agreement with resource-based theory, a resource composition giving greater financial access, measured in terms of size, higher leverage and liquidity, as well as the firm characteristics, age and industry affiliation, gives rise to higher labour demand and a higher job-creation level. The findings are consistent with results documented by previous studies including Acemoglu (2001), Greenwald and Stiglitz (1993) and Nickell and Nicolitsas (1999).

\section{Conclusions}

While the majority of previous empirical studies highlighted the determinants for job creation based on the industrial organization and macroeconomic perspective or on liquidity constraints, this paper presents a study of the firm-level determinants of job creation for Swedish micro firms. The study is performed using the GMM system approach and large instrumental variables to analyse a comprehensive cross-sectoral panel dataset pertaining to 12500 micro firms in 2007. 
The empirical results show that the size, age, liquidity, leverage and industry affiliation of micro firms, are positively significantly related to job-creation levels among sample firms. The positive impact of liquidity on job creation has been observed, confirming that larger size is associated with larger numbers of employees. The statistically significant relationship between leverage, liquidity and job-creation level indicates that a higher level of Swedish micro firms contributes to increased numbers of employees. The findings make clear that firm size and leverage are the two most important firm-level determinants for the magnitude of job creation among sample firms. In other words, the results confirm that debt availability has both statistical and economic relevance for job creation by micro firms. Overall, the empirical results suggest that the resource-based approach is at work in explaining the labour demand among the sample firms. The findings also provide evidence as to how the problems, such as information asymmetries, agency costs and moral hazards, which are related to imperfect capital markets reflecting on firms' capital structures, can affect labour demand decisions. In the context of capital and labour market imperfections, as in the Swedish economy, access to finance is important in obtaining financial resources and thereby hiring employees.

Given that the micro firm sector accounts for a considerable part of the Swedish labour market, the results have significant policy implications. Since firms' investments are an important aspect of job creation, an improvement in the Swedish capital market will encourage micro firms to employ more people. As such, any improvement should reduce information asymmetry, lower capital costs, and increase the availability of external finance for investment. Thus, the results of this study have important implications for determining banking policies.

\section{References}

Acemoglu, D. (2001). Credit market imperfections and persistent and Persistent Unemployment. European Economic Review, 45(4), 665-679. http://dx.doi.org/10.1016/S0014-2921(01)00107-6

Arellano, M., \& Bond, S. (1991). Some tests of specification for panel data: Monte Carlo evidence and an application to job creation equations. Review of Economic Studies, 58(2), 277-98. http://dx.doi.org/10.2307/2297968

Arnold, L. (2002). Financial market imperfections, labor market imperfections and business cycles. Scandinavian Journal of Economics, 104(1), 105-124. http://dx.doi.org/10.1111/1467-9442.00274

Audretsch, D. B. (1995). Innovation and Industry Evolution. Cambridge MIT Press, MA.

Audretsch, D., \& Elston, J. (2002). Does firm size matter? Evidence on the impact of liquidity constraints on firm investment behaviour in Germany. International Journal of Industrial Organization, 20(1), 1-17. http://dx.doi.org/10.1016/S0167-7187(00)00072-2

Autio, E. (2005). Creative tension, the significance of Ben Oviatt's and Patricia McDougall's article "Toward a theory of international new ventures". Journal of International Business Studies, 36(1), 9-19. http://dx.doi.org/10.1057/palgrave.jibs.8400117

Beck, T., Demirgüç-Kunt, A., \& Maksimovic, V. (2005). Financial and legal constraints to growth: Does firm size matter?. Journal of Finance, 60(1), 13777. http://dx.doi.org/10.1111/j.1540-6261.2005.00727.x

Benito, A. (2005). Financial pressure, monetary policy effects and inventories: Firm-level evidence from a market-based and a bank-based financial system. Econometrica, 72(286), 201-224.

Benito, A., \& Hernando, I. (2002). Extricate: Financial Pressure and Firm Behaviour in Spain. Banco de Espana-Servicio de Estudios. Documento de Trabajo no. 0227

Benito, A., \& Hernando, I. (2008). Labour demand, flexible contracts and financial factors: New evidence from Spain. Oxford Bulletin of Economics and Statistics, 70(3), 283-301. http://dx.doi.org/10.1111/j.1468-0084.2007.00494.x

Bond, S., \& Meghir, C. (1994). Dynamic investment models and the firm's financial policy. Review of Economics and Statistics, 61(2), 197-222. http://dx.doi.org/10.2307/2297978

Bond, S., \& Van Reenen, J. (2007). Microeconometric models of investment and job creation. in Heckman, J. and Leamer, E. (Eds), Handbook of Econometrics, 6, 4417-98. Elsevier, North Holland. http://dx.doi.org/10.1016/S1573-4412(07)06065-5

Bond, S., Harhof, D., \& Van Reenen, J. (1999). Investment, R\&D and financial constraints in Britain and Germany. Institute for Fiscal Studies Discussion Paper No. 99/5. (Forthcoming in Annales d'Economie et de Statistique). 
Broersma, L., \& Gautier, P. (1997). Job creation and job destruction by small firms: An empirical investigation for the Dutch manufacturing sector. Small Business Economics, 9(3), 211-224. http://dx.doi.org/10.1023/A:1017982719207

Cantor, R. (1990). Effects of leverage on corporate investment and hiring decisions. Federal Reserve Bank of New York Quarterly Review, 15(4), 31-41.

Carpenter, R. E., \& Petersen, B. C. (2002). Is the growth of small firms constrained by internal finance?. The Review of Economics and Statistics, 84(2), 298-309. http://dx.doi.org/10.1162/003465302317411541

Castrogiovanni, G. (1996). Pre-startup planning and the survival of new small businesses: theoretical linkages. Journal of Management, 22(6), 801-822. http://dx.doi.org/10.1177/014920639602200601

Conner, K. R., \& Prahalad, C. K. (1996). A resource-based theory of the firm: Knowledge versus opportunism. Organization Science, 7(5), 477-501. http://dx.doi.org/10.1287/orsc.7.5.477

Evans, D., \& Jovanovic, B. (1989). An estimated model of entrepreneurial choice under liquidity constraints. Journal of Political Economy, 97(4), 808-827. http://dx.doi.org/10.1086/261629

Fagiolo, G., \& Luzzi, A. (2006)'Do Liquidity Constraints matter in explaining firm size and Growth? Some Evidence from the Italian Manufacturing Industry. Industrial and Corporate Change, 15(1), 1-39. http://dx.doi.org/10.1093/icc/dtj001

Fazzari, S. M., Hubbard, R. G., \& Petersen, B. C. (1988). Financing constraints and corporate investment. Brookings Papers on Economic Activity, 19(1), 141-95. http://dx.doi.org/10.2307/2534426

Funke, M., Maurer, W., Siddiqui, S., \& Strulik, H. (1998). The job creation financing nexus: Evidence from a panel of West German firms. Small Business Economics, 11(3), 225-235. http://dx.doi.org/10.1023/A:1007959512867

Gertler, M., \& Gilchrist, S. (1993). The role of credit market imperfections in the monetary transmission mechanism: Arguments and evidence. Scandinavian Journal of Economics, 95(1), 4364. http://dx.doi.org/10.2307/3440134

Greenwald, B., \& Stiglitz, J. (1993). Financial market imperfection and business cycles. Quarterly Journal of Economics, 108(1), 74-114. http://dx.doi.org/10.2307/2118496

Guariglia, A., \& Mateut, S. (2006). Credit channel, trade credit channel, and inventory investment: Evidence from a panel of UK firms. Journal of Banking and Finance, 30(10), 2835-56. http://dx.doi.org/10.1016/j.jbankfin.2005.11.002

Hall, B. H. (1987). The relationship between firm size and firm growth in the U.S. manufacturing sector. Journal of Industrial Economics, 35(4), 583-605. http://dx.doi.org/10.2307/2098589

Hamilton, R. T., \& Fox, M. A. (1998). The financing preferences of small firm owners. International Journal of Entrepreneurial Behaviour \& Research, 4(3), 239-48. http://dx.doi.org/10.1108/13552559810235529

Heisz, A., \& LaRochelle-Côté, S. (2004). Corporate financial leverage in Canadian manufacturing: Consequences for job creation and inventories. Canadian Journal of Administrative Sciences, 21(2), 111-128. http://dx.doi.org/10.1111/j.1936-4490.2004.tb00328.x

Hubbard, R. G. (1998). Capital market imperfections and investment. Journal of Economic Literature, 36(1), 193-225.

Hutchinson, J., \& Xavier, A. (2006). Comparing the impact of credit constraints on the growth of SMEs in a transition country with an established market economy. Small Business Economics, 27(2),169-179. http://dx.doi.org/10.1007/s11187-005-4412-3

Jovanovic, B. (1982). Selection and the evolution of industry. Econometrica, 50(3), 649-670. http://dx.doi.org/10.2307/1912606

Lang, L., Ofek, E., \& Stulz, R. M. (1996). Leverage, investment, and firm growth. Journal of Financial Economics, 40(1), 3-29. http://dx.doi.org/10.1016/0304-405X(95)00842-3

Modigliani, F., \& Miller, M. H. (1958). The cost of capital, corporate finance, and the theory of investment. American Economic Review, 48(3), 261-297.

Myers, S. C. (1984). The capital structure puzzle. Journal of Finance, 39(3), 575-592. http://dx.doi.org/10.2307/2327916 
Myers, S. C., \& Majluf, N. S. (1984). Corporate financing and investment decisions when firms have information that investors do not have. Journal of Financial Economics, 13(1), 187-221. http://dx.doi.org/10.1016/0304-405X(84)90023-0

Nickell, S., \& Nicolitsas, D. (1999). How does Financial Pressure Affect Firms?. European Economic Review, 43(8), 1435-56. http://dx.doi.org/10.1016/S0014-2921(98)00049-X

Nickell, S., \& Wadhwani, S. (1991). Job creation determination in British industry: Investigation using micro-data. Review of Economic Studies, 58, 955-969. http://dx.doi.org/10.2307/2297946

Oliveira, B., \& A. Fortunato. (2006). Firm growth and liquidity constraints: A dynamic analysis. Small Business Economics, 27(2-3), 139-156. http://dx.doi.org/10.1007/s11187-006-0006-y

SCB: Statistics Sweden. (2012). http://www.scb.se/Pages/PressRelease__299961.aspx.

Sharpe, S. A. (1994). Financial market imperfections, firm leverage, and the cyclicality of job creation. American Economic Review, 84(4), 1060-1074.

Singh, A., \& Whittington, G. (1975). The size and growth of firms. Review of Economic Studies, 42(1), 15-26.

Stiglitz, J., \& Weiss, A. (1981). Credit rationing in markets with imperfect information. American Economic Review, 71(3), 393-410.

Wernerfelt, B. (1984). A resource-based view of the firm. Strategic Management Journal, 5(2), 171-180. http://dx.doi.org/10.1002/smj.4250050207

Winker. P. (1999). Causes and effects of financing constraints at the firm level: Some microeconometric evidence. Small Business Economics, 12(1), 169-181. http://dx.doi.org/10.1023/A:1008035826914

Yazdanfar, D. (2011). The growth determinants among Swedish SMEs: Evidence from firm-level data. International Journal of Business and Globalisation, 6(3-4), 313-328. http://dx.doi.org/10.1504/IJBG.2011.039390 